\title{
STATISTICAL PROCESS CONTROL (SPC): A CONTROL TOOL AGAINST WASTE OF INPUTS IN BRAZILIAN DAIRY
}

\author{
Tiago Henrique de Paula Alvarenga \\ Federal University of Technology - Paraná (UTFPR), Brazil \\ E-mail: thpalvarenga@hotmail.com
}

Ademir José de Abreu Instituto de Ensino Superior Presidente Tancredo de Almeida Neves,

E-mail: ademirjabreu@hotmail.com

\begin{abstract}
Cassiano Moro Piekarski Federal University of Technology - Paraná (UTFPR), Brazil E-mail: cassianopiekarski@gmail.com

Juliana Vitória Messias Bittencourt Federal University of Technology - Paraná (UTFPR), Brazil

E-mail: julianavitoria@utfpr.edu.br

Eloiza Aparecida Silva Ávila de Matos Federal University of Technology - Paraná (UTFPR), Brazil E-mail: elomatos@utfpr.edu.br
\end{abstract}

Submission: $21 / 09 / 2013$ Accept: 05/10/2013

\section{ABSTRACT}

By reason of the requirements of quality on the part of consumers and regulatory agencies, the dairy industries require tools capable of optimizing their processes in virtue of threats from countries which have a lower cost of production. The Statistical Process Control (SPC) is a powerful tool to evaluate and monitor the process in relation to their stability. This paper presents an application of Statistical Process Control (SPC) in a dairy plant located in the south of Minas Gerais. The process analyzed was the packaging of butter in $200 \mathrm{~g}$ pots. The purpose of this article is to identify the actual state of the filling process of butter in this dairy and compare them with the requirements established by legislation. Therefore, was used samples and control charts to demonstrate the current state of the process and normality tests, in particular the t-student. The results demonstrate that the 
INDEPENDENT JOURNAL OF MANAGEMENT \& PRODUCTION (IJM\&P)

http://www.ijmp.jor.br

v. 5, n. 1, October - January 2014.

ISSN: 2236-269X

DOI: 10.14807/ijmp.v5i1.140

industry does not harm the consumer and that is faithful to the legislation. However, it was identified that in case the industry presents an overweight in nominal content of each package, which leads to considerable injury once the feedstock used in the production of butter (cream) is of great economic value.

Keywords: Statistical process control; control charts; dairy.

\section{INTRODUCTION}

Milk production and its derivatives play an important role on the national stage, whether in economics, is the social aspect as employment generation, maintenance of the population in rural areas and improving the quality of life in rural areas (CAPUCHO; PARRÉ, 2012).

The importance of this industry can be seen in the context of agribusiness, where it is referred to as one of the leading sectors in terms of national income and tax revenues (SOUZA, 2006). O leite e seus derivados estão entre os seis primeiros produtos mais importantes da agropecuária nacional, ficando à frente de produtos de culturas tradicionais como café e o arroz. Para cada real acrescido na produção no sistema agroindustrial do leite, há um crescimento de, aproximadamente, cinco reais no aumento do Produto Interno Bruto - PIB, o que coloca o agronegócio do leite à frente de setores importantes como o da siderurgia e $\mathrm{O}$ da indústria têxtil (EMBRAPA, 2003).

However, the domestic market is being threatened by products from the countries of the Southern Common Market (MERCOSUR) in terms of its low production cost. Thus, the competitiveness and survival of dairy products are linked to a national quality management. By this fact, the main determinants for longevity of dairy is a national quality management based on reducing costs and waste, since most of the population still considers the price as a major factor in the purchase decision (SCALCO; TOLEDO, 2002). The end of the price-fixing of milk in 1991 and the economic opening of the country exposed the weaknesses and deficiencies in organization and technology in the dairy sector national (WINCLER; SANTOS; MACHADO, 2013).

For industries, one of the key to success is to stabilize their processes ensuring product reliability by reducing waste. An accepted definition of quality is to reduce the variability that the smaller, the better the reliability and acceptance of the 
INDEPENDENT JOURNAL OF MANAGEMENT \& PRODUCTION (IJM\&P)

http://www.ijmp.jor.br

v. 5, n. 1, October - January 2014.

ISSN: 2236-269X

DOI: 10.14807/ijmp.v5i1.140

product or service. To reduce variability tools Statistical Process Control (SPC) to demonstrate efficient stabilization of production processes (KHEDIRI; WEIHS; LIMAM, 2010; MILAN; FERNANDES, 2002).

The Statistical Process Control (SPC) is a set of statistical tools for quality oriented problem solving environment in processes and decision making by managers. The CEP seeks accuracy in manufacturing, using data to analyze the process. In the CEP process prevents loss (waste) products through control limits (CHAKRABORTY; TAH, 2006; DINIZ, 2001). It is quite simple being used in various industries worldwide. Through it, it is possible to control important features of the product and the process instantly, ensuring quality levels at an affordable cost. The SPC uses statistics to analyze the limitations of the product and process (NOMELINI; FERREIRA; OLIVEIRA, 2009; SINGH; GILBREATH, 2002).

The SPC is composed of seven major tools, which were understood by histograms, check sheets, Pareto charts, cause-effect diagrams, diagrams concentration defect (stratification), scatter diagrams, and control charts (Vieira, 1999). Among the tools SPC control charts are one of the most popular tools. These graphics can be based on attributes, or variables (SOUZA; RIGÃO, 2005).

A control chart is composed of three parallel lines, one central represents the average value $(\mathrm{CL})$, the lower representing the lower control limit (LCL) and upper one representing the upper control limit $(\mathrm{UCL})$. Are presented on points representing the samples taken at various times of the process (DINIZ, 2001; VIEIRA, 1999).

The control process is performed by measuring the variables in separate points in control charts. During the measurements, the results are checked against the control limits which are expected according to the desired pattern. The results obtained from the measurements indicates that the process has random or specific causes of variability (KHEDIRI; WEIHS; LIMAM, 2010; PAESE; CATEN; RIBEIRO, 2001).

So that the process is under control it is necessary that your points are within the control limits and your presentation is random at the top and bottom of the middle line representing the quality characteristic (VIEIRA, 1999; DINIZ, 2001; CARVALHO, 2008). The measurements show that outside the control limits of variability are considered special, i.e. affecting the quality of the product. Upon detecting such 
INDEPENDENT JOURNAL OF MANAGEMENT \& PRODUCTION (IJM\&P)

http://www.ijmp.jor.br

v. 5, n. 1, October - January 2014.

ISSN: 2236-269X

DOI: 10.14807/ijmp.v5i1.140

causes of variation can act on the process to improve the quality of the product continuously (CARVALHO, 2008; DINIZ, 2001; MICHEL; FOGLIATTO, 2002; RAMOS, 2000; VIEIRA, 1999).

Although the agrifood sector present an unquestionable relevance to Brazil, is only seen a small amount of research surrounding the issue of quality management in the sector (TOLEDO; BATALHA; AMARAL, 2000). Given the above, this paper aims to apply Statistical Process Control (SPC) in the process of filling of butter in a Cooperative Dairy located in Lavras in southern Minas Gerais and check if this process has stability and content $200 \mathrm{~g}$ pots of butter is within the standards of the National Institute of Metrology and Industrial Quality (INMETRO).

\section{MATERIAL AND METHODS}

The study was conducted under a Cooperative Dairy Lavras located in the south of Minas Gerais. The Statistical Process Control (SPC) was applied in the process of filling of butter in $200 \mathrm{~g}$ pots in order to verify that the products are under statistical control and meet specifications INMETRO No. 248, July 17, 2008. To obtain the weights of the pots of butter (finished product), they were weighed on the same plant by using two scales Gehaka - semi-analytical model BK-300, with a maximum capacity of $310 \mathrm{~g}$, as recorded in INMETRO INMETRO seal 188 / 2003. The two scales showed no significant difference in the values acquired through weighing, only differences being observed in the third house after of the point.

The data analyzed correspond to eight productions (batches) of butter in $200 \mathrm{~g}$ pots - between the months of May and August of 2011. To carry out all the procedures for applying the SPC (applying the Student $t$ test and Wilcoxon test) was used R-software, as well as their respective libraries for each proposed analysis thus were made use of packages: library (qcc); require (gdata); library (BSDA) and function $t$ test. Through the R-software, were generated consolidated statistics as the histogram, control charts for variables and the t test. The conventions used in control charts were described as upper specification limit and lower specification limit, which match the criteria defined by INMETRO in the ordinance in question. The lower and upper control limits of the statistical analysis are determined in accordance with the process variability purchased in batches surveyed. 


\section{INDEPENDENT JOURNAL OF MANAGEMENT \& PRODUCTION (IJM\&P)}

http://www.ijmp.jor.br

v. 5, n. 1, October - January 2014.

ISSN: 2236-269X

DOI: 10.14807/ijmp.v5i1.140

The National Institute of Metrology, Standardization and Industrial Quality (INMETRO) regularly conducts tests concerning the veracity of a product in relation to its weight, volume and diameter. Such tests are reported in the media and the credibility of the industries analyzed is put to the test with such disclosure. It is a federal agency under the Ministry of Development, Industry and Foreign Trade, whose mission is to provide confidence to the Brazilian society in the measurements and products through metrology and conformity assessment, promoting the harmonization of consumer relations, innovation and the country's competitiveness (INMETRO, 2011).

The butter milk derivative is produced and marketed in weight (grams and kilogram) without the presence of the consumer. In this respect, INMETRO No. 248, July 17, 2008 aims to establish criteria for checking the actual content of premeasured products with nominal content (Qn) equal, expressed in units of the International System of Units. This Ordinance applies to the metrological control of pre-measured products in manufacturing environments, deposits and retail outlets.

According to INMETRO No. 248, July 17, 2008, Product Pre-Measured content rating equal is defined as any packaged product and / or measured without the presence of the consumer, with equal and predetermined nominal content in packaging during manufacturing. In the production process it is clear that there are variability's. At this point, the said Ordinance establishes individual tolerances for checking the weight / volume of the product in relation to its liquidity. Table 1 provides acceptable tolerance by the standard:

Table 1: Tolerances for individual allowable mass and volume

\begin{tabular}{l|cc}
\hline & \multicolumn{2}{c}{ INDIVIDUAL TOLERANCE (T) } \\
\hline $\begin{array}{l}\text { Nominal content (Qn) } \\
\text { grams or millgrams }\end{array}$ & Percentage (\%) of Qn & grams or millgrams \\
$\mathbf{5}$ to $\mathbf{5 0}$ & - & - \\
$\mathbf{5 0}$ to $\mathbf{1 0 0}$ & - & 4,5 \\
$\mathbf{1 0 0}$ to $\mathbf{2 0 0}$ & 4,5 & - \\
$\mathbf{2 0 0}$ to $\mathbf{3 0 0}$ & - & - \\
$\mathbf{3 0 0}$ to $\mathbf{5 0 0}$ & - & - \\
$\mathbf{5 0 0}$ to $\mathbf{1 0 0 0}$ & - & 15 \\
$\mathbf{1 0 0 0}$ to $\mathbf{1 0 0 0 0}$ & 1,5 & - \\
$\mathbf{1 0 0 0}$ to $\mathbf{1 5 0 0 0}$ & - & 150 \\
$\mathbf{1 5 0 0 0}$ to $\mathbf{2 5 0 0 0}$ & 1 & - \\
\hline & Source: INMETRO (2008)
\end{tabular}




\section{INDEPENDENT JOURNAL OF MANAGEMENT \& PRODUCTION (IJM\&P)}

http://www.ijmp.jor.br

v. 5 , n. 1 , October - January 2014

ISSN: 2236-269X

DOI: 10.14807/ijmp.v5i1.140

Since pots of butter (pots) are $200 \mathrm{~g}$ obeys individual tolerance $9 \mathrm{~g}$ contained in Table 1. The INMETRO No. 248 , July 17,2008 , this content is already subtracted the average weight of packaging, in this context, this individual tolerance it is only the product.

However, INMETRO No. 248, July 17, 2008, also provides for batches produced the quantity of items to be sampled and the amount of items containing liquid below the individual tolerance contained in Table 1. Table 2 presents the sample to the control and maximum number of defective items:

Table 2: Sample for control and maximum number of defective items

\begin{tabular}{|c|c|c|c|}
\hline Batch Size & Sample Size & $\begin{array}{l}\text { Criteria for } \\
\text { acceptance } \\
\text { average }\end{array}$ & $\begin{array}{c}\text { Maximum } \\
\text { defective below } \\
\text { Qn-T }\end{array}$ \\
\hline $\begin{array}{l}9 \text { to } 25 \\
26 \text { to } 50 \\
51 \text { to } 149 \\
150 \text { to } 4000 \\
4001 \text { to } 10000\end{array}$ & $\begin{array}{c}5 \\
13 \\
20 \\
32 \\
80 \\
\end{array}$ & $\begin{array}{l}X \geq Q n-2.059 \times S \\
X \geq Q n-0.847 \times S \\
X \geq Q n-0.640 \times S \\
X \geq Q n-0.485 \times S \\
X \geq Q n-0.295 \times S\end{array}$ & $\begin{array}{l}0 \\
1 \\
1 \\
2 \\
5\end{array}$ \\
\hline
\end{tabular}

Regarding Table 2, to accept the corresponding average of the sample as mean $(X)$, must be greater or equal to the nominal capacity $\left(Q_{n}\right)$, unless the tabular values contained in the table for each sample size, multiplied by the deviation standard (S) of the samples collected.

\section{RESULTS}

The samples were arranged according to the eight batches sampled between May and August 2011, which are presented in Table 3 arranged in eight (08) samples, divided into rational subgroups with $n=32$ :

The sample size was set at $n=32$, according to INMETRO No. 248 , July 17 , 2008 , for the production of dairy fits the average of 1,000 pots of butter per batch. Therefore, it was determined that the jump from one sample to another 31 was produced items, i.e. items produced every 31 withdrawing a sample and so forth.

In the literature (DINIZ, 2000; MONTGOMERY, 2009; RAMOS, 1999), is very easily to control charts for variables to have answers expressed by a number on a scale discrete measures. Thus, in Table 4, shows the limits of the control charts as well as the main equations adopted in this work: 
INDEPENDENT JOURNAL OF MANAGEMENT \& PRODUCTION (IJM\&P)

http://www.ijmp.jor.br

v. 5, n. 1, October - January 2014.

ISSN: 2236-269X

DOI: 10.14807/ijmp.v5i1.140

Table 3: Samples collected in the period from May to August/2011

\begin{tabular}{cccccccc}
\hline Sample 1 & Sample 2 & Sample 3 & Sample 4 & Sample 5 & Sample 6 & Sample 7 & Sample 8 \\
\hline 202.4 & 201.4 & 199.3 & 203.0 & 201.9 & 203.2 & 202.6 & 201.1 \\
205.8 & 209.5 & 208.8 & 205.6 & 205.7 & 207.4 & 204.2 & 204.2 \\
205.1 & 208.3 & 209.3 & 203.2 & 204.5 & 207.6 & 207.7 & 203.1 \\
205.5 & 209.5 & 209.3 & 203.9 & 208.2 & 209.3 & 208.4 & 204.0 \\
206.6 & 216.0 & 206.0 & 202.8 & 210.1 & 209.1 & 209.6 & 207.3 \\
205.3 & 211.0 & 207.6 & 205.7 & 210.6 & 208.5 & 210.2 & 207.7 \\
206.4 & 208.7 & 208.4 & 204.5 & 209.6 & 208.6 & 208.9 & 207.8 \\
207.6 & 209.7 & 210.2 & 207.5 & 209.4 & 210.5 & 211.5 & 208.3 \\
204.4 & 207.2 & 209.1 & 208.9 & 209.7 & 209.2 & 212.3 & 210.6 \\
205.4 & 207.1 & 206.2 & 208.0 & 210.2 & 208.5 & 211.2 & 210.4 \\
206.1 & 208.3 & 206.4 & 210.7 & 210.6 & 210.7 & 210.3 & 208.2 \\
206.6 & 208.0 & 206.2 & 207.7 & 210.5 & 211.0 & 209.0 & 208.5 \\
206.1 & 208.1 & 207.1 & 211.7 & 212.6 & 209.3 & 211.6 & 209.5 \\
206.7 & 207.9 & 208.7 & 214.5 & 211.3 & 208.4 & 211.8 & 210.3 \\
206.8 & 206.8 & 208.9 & 212.9 & 211.1 & 211.2 & 210.4 & 211.7 \\
206.9 & 207.7 & 203.9 & 213.5 & 209.1 & 210.1 & 209.2 & 210.6 \\
206.6 & 208.2 & 206.2 & 209.4 & 208.5 & 208.4 & 210.1 & 211.0 \\
206.1 & 206.9 & 205.8 & 210.5 & 209.5 & 208.5 & 209.2 & 212.4 \\
216.0 & 207.3 & 206.6 & 209.9 & 211.1 & 210.2 & 211.5 & 211.1 \\
210.5 & 208.9 & 206.7 & 208.6 & 210.0 & 211.8 & 209.8 & 211.9 \\
215.7 & 207.7 & 206.9 & 207.7 & 208.9 & 210.7 & 212.4 & 210.2 \\
210.6 & 210.7 & 206.9 & 208.5 & 211.6 & 209.4 & 210.1 & 208.6 \\
216.1 & 208.7 & 207.5 & 208.3 & 207.8 & 211.7 & 211.3 & 210.6 \\
206.2 & 209.9 & 210.4 & 209.5 & 211.6 & 208.5 & 209.1 & 212.3 \\
215.2 & 209.1 & 207.9 & 206.3 & 213.5 & 209.4 & 211.5 & 210.3 \\
203.1 & 210.2 & 208.6 & 208.7 & 211.6 & 210.7 & 212.2 & 208.2 \\
214.1 & 210.4 & 207.1 & 210.2 & 208.5 & 208.9 & 211.3 & 212.8 \\
213.1 & 216.2 & 207.5 & 211.3 & 210.6 & 208.4 & 210.7 & 210.2 \\
203.8 & 209.2 & 207.8 & 212.6 & 210.7 & 211.0 & 211.4 & 212.1 \\
203.8 & 206.8 & 207.3 & 209.5 & 214.4 & 212.6 & 212.5 & 210.4 \\
213.9 & 211.0 & 209.2 & 208.4 & 208.2 & 210.6 & 211.4 & 211.3 \\
213.0 & 208.1 & 207.3 & 207.6 & 209.4 & 209.0 & 212.5 & 210.6 \\
\hline & & & Source: Survey data & & & \\
& 20.5 &
\end{tabular}

To prove that the average weight of butter jars fit the average interval specified by ordinance, formulated two hypotheses, where $H_{0}: \mu_{0}-\mu_{1}$ (average limits are equal); and, $H_{1}: \mu \mu_{0}=\not \mu_{1}$ (average limits are different). In this respect, Ferreira (2009) describes a good test for this type of comparison is the average student $t$ test. Therefore, reject $H_{0}$ in favor of $H_{1}$ at a significance level of $5 \%$, in other words, the average interval specified is $191 \mathrm{~g}$ and $209 \mathrm{~g}$, while the average interval was found in the sample of $208.60 \mathrm{~g}$ and $209.29 \mathrm{~g}$. The Table 5 shows the results of the comparisons $\bar{x}=200 \mathrm{~g}$ and the average sample: 
INDEPENDENT JOURNAL OF MANAGEMENT \& PRODUCTION (IJM\&P)

http://www.ijmp.jor.br

v. 5, n. 1, October - January 2014.

ISSN: 2236-269X

DOI: $10.14807 /$ ijmp.v5i1.140

Table 4: Limits of graphs and equations adopted in the research

\begin{tabular}{|c|c|c|}
\hline & $\begin{array}{c}\text { Mean and standard } \\
\text { deviation }\end{array}$ & $\begin{array}{c}\text { Mean and standard deviation } \\
\text { unknown }\end{array}$ \\
\hline$C L$ & $\mu_{Y}$ & $\bar{Y}$ \\
\hline UCL e $L C L$ & $\mu_{Y} \pm k \sigma_{Y}$ & $\bar{Y} \pm k s_{Y}$ \\
\hline \multicolumn{3}{|c|}{ Formulas adopted in line with INMETRO 248/2008 } \\
\hline Average & $\bar{x}_{i}=\frac{\sum_{i=1}^{n} x_{i}}{n}$ & $\begin{array}{l}\bar{x}_{i} \text { is the average of the sampled values } \\
x_{i} \text { is the observed value of each point } \\
n \text { is the sample size }\end{array}$ \\
\hline Deviation & $S=\sqrt{\sum_{i=1}^{n} \frac{\left(x_{i}-\bar{x}\right)^{2}}{n-1}}$ & $\begin{array}{l}\bar{X}_{i} \text { is the average of the sampled values } \\
X_{i} \text { is the observed value of each point } \\
S \text { is the standard deviation of the sample } \\
n \text { is the sample size }\end{array}$ \\
\hline Jump & $x_{i}=\frac{z_{i}}{n}$ & $\begin{array}{ll}x_{i} & \text { the jump is performed for each sample } \\
Z_{i} & \text { is the lot size produced } \\
n & \text { is the sample size }\end{array}$ \\
\hline
\end{tabular}

Table 5. Results of comparisons between $\bar{x}=200 \mathrm{~g}$ and the average sample

\begin{tabular}{cccccc}
\hline Item & LCL & CL & UCL & p-value & Assurance \\
\hline Global & 208.60 & 208.94 & 209.29 & $2.20 \mathrm{E}-16$ & $95 \%$ \\
Sample 1 (Y1) & 206.66 & 208.17 & 209.67 & $2.67 \mathrm{E}-09$ & $95 \%$ \\
Sample 2 (Y2) & 207.96 & 208.89 & 209.82 & $2.20 \mathrm{E}-16$ & $95 \%$ \\
Sample 3 (Y3) & 206.61 & 207.35 & 208.09 & $2.20 \mathrm{E}-16$ & $95 \%$ \\
Sample 4 (Y4) & 207.39 & 208.49 & 209.58 & $2.20 \mathrm{E}-16$ & $95 \%$ \\
Sample 5 (Y5) & 208.86 & 209.73 & 210.61 & $2.20 \mathrm{E}-16$ & $95 \%$ \\
Sample 6 (Y6) & 208.83 & 209.45 & 210.07 & $2.20 \mathrm{E}-16$ & $95 \%$ \\
Sample 7 (Y7) & 209.39 & 210.18 & 210.98 & $2.20 \mathrm{E}-16$ & $95 \%$ \\
Sample 8 (Y8) & 208.27 & 209.29 & 210.31 & $2.20 \mathrm{E}-16$ & $95 \%$ \\
\hline \multicolumn{5}{c}{ Source: Survey data }
\end{tabular}

It is clarified that the test was applied globally (all elements of the sample) and then to the sample group only as a precaution, in order to verify if any sample would cause variation between them. Note that the test was significant at $95 \%$ confidence level with $\mathrm{p}$-value greater than 16th after of the point.

Figure 1 shows the control charts generated by $\mathrm{R}$ software with sample data, organized as follows: R Chart - Graph control amplitude; S Chart - Graph Control Standard Deviation; xbar Chart (left) - Graph Control Average of the natural limits of the process; xbar Chart (right) - Average Control graph with the limits INMETRO. 
Figure 1: Graphs of the research generated by the software $R$
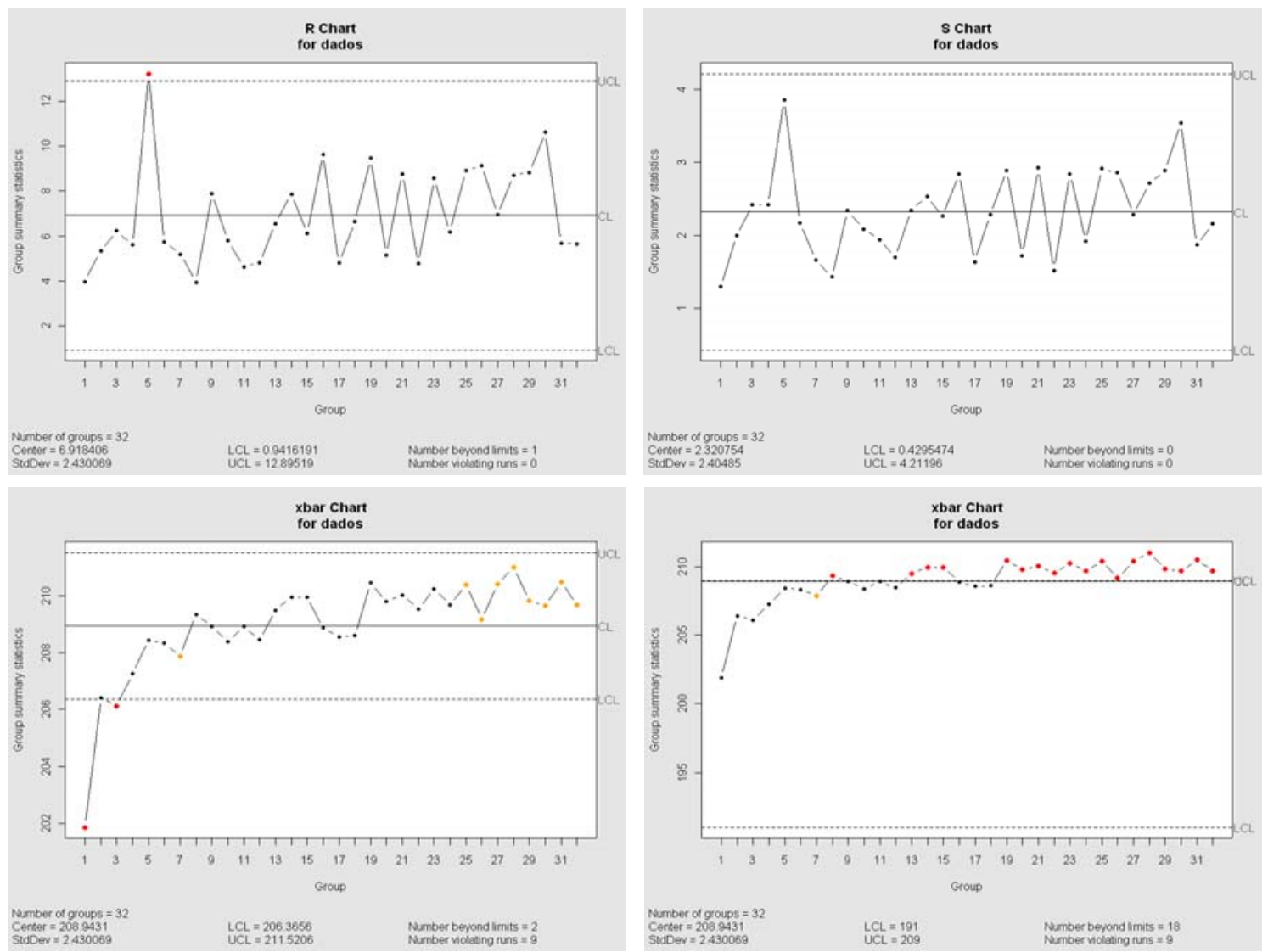

Source: Survey data

A distribution cannot be defined solely by their average, requiring a knowledge of dispersion around the sample mean. This knowledge can be acquired through the graph of the standard deviation or the graph of amplitude (DINIZ, 2001).

The values of the samples in Chart 1 (amplitude) had low variability, and only one sample (sample 5) was presented outside the control limits. In Chart 2 (standard deviation) all samples were stable, with all the elements contained within the lower and upper control.

Charts 3 and 4 show the natural limits of the samples (Chart 3) and the specification limits (Chart 4). Note that in both graphs for red-flagged samples, whose significance is the lack of stability. According to Montgomery (2009), processes that have special causes of variation are called out of statistical control, since they are responsible for the increase in manufacturing costs. The same author also states that the stability of a process cannot be measured only by the fact that the points are 
INDEPENDENT JOURNAL OF MANAGEMENT \& PRODUCTION (IJM\&P)

http://www.ijmp.jor.br

v. 5, n. 1, October - January 2014.

ISSN: 2236-269X

DOI: 10.14807/ijmp.v5i1.140

within the control limits. He argues that there are cases in which the existence of more than 7 points between sequential mean and limits, sets up lack of stability.

The ability of a process can be understood as the natural variability of item regarding their specifications. Thus, the ability to identify a process, it is necessary to use capability indices, the most used and $\mathrm{Cp}$ index $\mathrm{Cpk}$. Figure 2 shows two graphs of process capability of the dairy:

Figure 2: Graphs of capacity generated by the software $R$

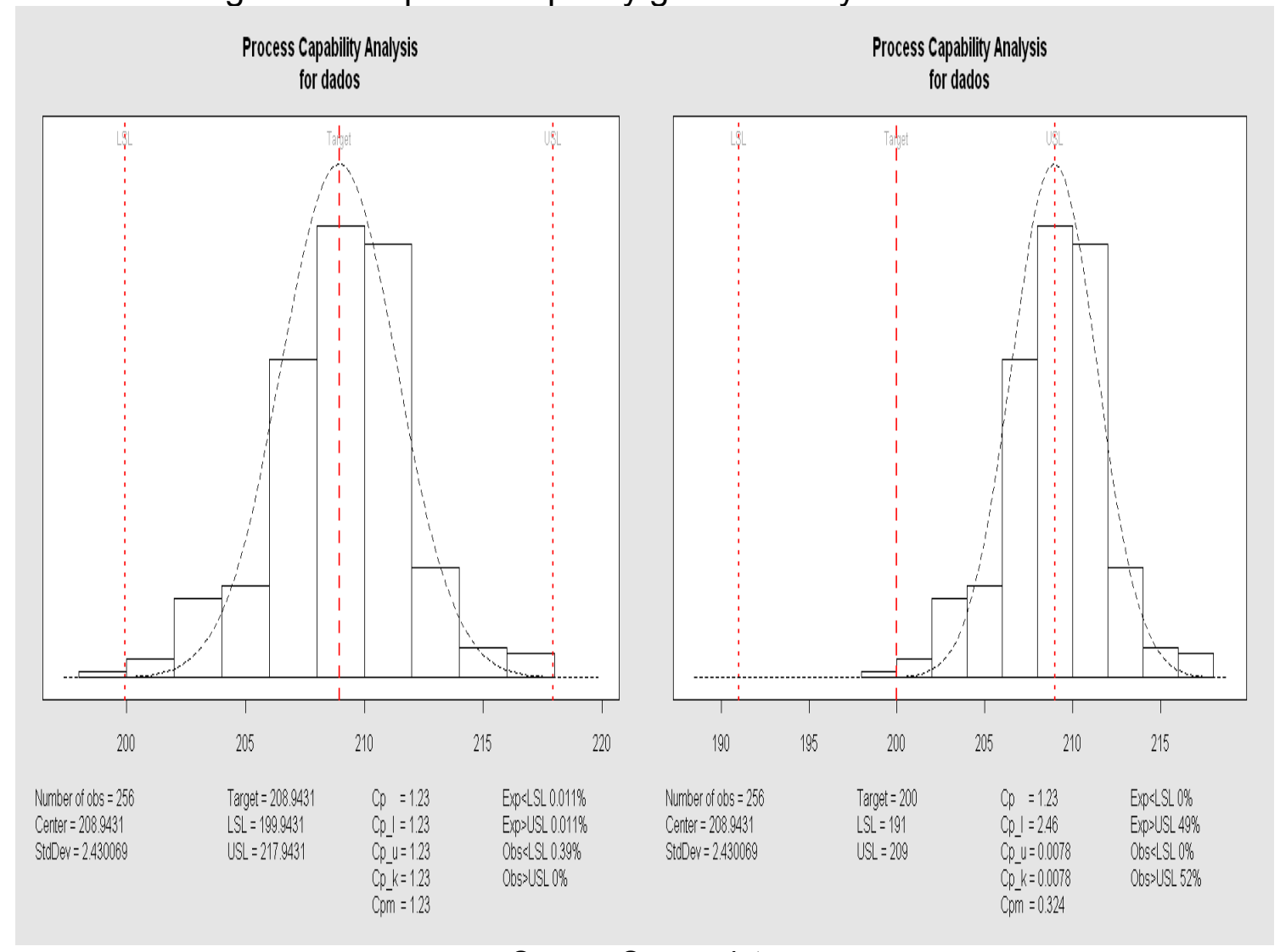

Source: Survey data

The index Cp is defined by Ramos (2000) as being the ratio between the total dispersion and engineering tolerate the procedure. The same authors also described that this index compares the total variation allowed by specification with the dispersion consumed by the process. If $\mathrm{Cp}>1$, this indicates that the process is capable of achieving the specification. Already another index (Cpk) is also defined by the same author as the average distance evaluation process regarding the specification limits, taking into account that it is lower, i.e. more critical. If $\mathrm{Cpk}>1$, then the process is capable. Montgomery (2004) argues that $\mathrm{Cp}$ analyzes the potential capacity of the process, while Cpk analyzes the effective capacity. 
INDEPENDENT JOURNAL OF MANAGEMENT \& PRODUCTION (IJM\&P)

http://www.ijmp.jor.br

v. 5, n. 1, October - January 2014.

ISSN: 2236-269X

DOI: 10.14807/ijmp.v5i1.140

Note in the chart 1 of Figure 2, both the $\mathrm{Cp}$ value as the $\mathrm{Cpk}$ is $>1$, the two indices of 1.23. Already chart 2 of the same figure shows the index $\mathrm{Cp}$ with the same 1.23 and Cpk index of 0.0078. This difference between the indices Cpk charts, occurs because of the first to be generated by the natural limits of the process and the second by the specification limits. The process analyzed as shown in Figure 3, shows low variability in their control limits with a standard deviation of 2.43; however is outside the limits specified by ordinance mentioned.

\section{CONCLUSIONS}

The implementation of the SPC in the filling dairy process identified instability and even still possible to know the number of grams in losses filling product (butter) excess in $200 \mathrm{~g}$ pots.

The dairy analyzed satisfactorily meets the minimum specifications of INMETRO No. 248, July 17, 2008, which establishes a lower control limit of $191 \mathrm{~g}$ and an average weight of $200 \mathrm{~g}$. However, it is observed that the average interval of the weights is not centered in $200 \mathrm{~g}$, according to the results of the tests: Student $\mathrm{t}$ and Wilcoxon. The true average is centered on $208.94 \mathrm{~g}$ with $95 \%$ confidence. Thus, it appears that the company is sending over $4.47 \%$ of output per batch equivalent to $8,943 \mathrm{~g}$.

It is observed that on the product weight must be corrected in order to reduce operating costs of the company, since 45 pots $(8.943 \mathrm{~g})$ of butter are lost production (batch). The process has low variability, but it is mostly above the upper specification limit. For this purpose, it is recommended to realign the process, maintaining low rates of change, so that it does not cause damage to the company which results in considerable loss since the raw material used in the production of butter (cream) is great economic value in the dairy industry.

\section{REFERENCES}

CAPUCHO, T. O.; PARRÉ, J. L. (2012) Milk production in Paraná: a study considering the spatial effects. Informe GEPEC Journal. v. 16, n: 1, p. 112-127.

CARVALHO, M. M.; (2008) Qualidade. In: BATALHA, M. O. Introdução à engenharia da produção. Rio de Janeiro: Elsevier. cap. 4, p. 53-77.

CHAKRABORTY, S.; TAH, D. (2006) Real time statistical process advisor for effective quality control. Decision Support Systems. v. 42, p. 700-711. 
INDEPENDENT JOURNAL OF MANAGEMENT \& PRODUCTION (IJM\&P)

http://www.ijmp.jor.br

v. 5, n. 1, October - January 2014.

ISSN: 2236-269X

DOI: 10.14807/ijmp.v5i1.140

DINIZ, M. G. (2001) Desmistificando o controle estatístico de processo. São Paulo: Artliber.

EMBRAPA. (2003) Empresa Brasileira de Agropecuária. Embrapa - Gado de leite. Sistema de Produção de Leite (Zona da Mata Atlântica), jan. 2003. Disponível em: < http://sistemasdeproducao.cnptia.embrapa.br/FontesHTML/Leite/LeiteZonadaMataAt lantica/index.htm > Acesso: 21 ago. 2012.

FERREIRA, D. F. (2009) Estatística básica. Lavras: UFLA.

INMETRO (2008) - INSTITUTO NACIONAL DE METROLOGIA, NORMALIZAÇÃO E QUALIDADE INDUSTRIAL. Portaria INMETRO № 248, de 17 de julho de 2008.

KHEDIRI, I. B.; WEIHS, C.; LIMAM, M. (2010) Support Vector Regression control charts for multivariate nonlinear autocorrelated processes. Chemometrics and Intelligent Laboratory Systems. v. 103, p. 76-81.

MILAN, M.; FERNANDES, R. A. T. (2002) Quality of tillage operations by statistical process control. Scientia Agricola. v.59, n:2, p. 261-266, abr/jun.

MONTGOMERY, D. C. (2009) Introdução ao controle estatístico de qualidade. Rio de Janeiro: LTC.

NOMELINI, Q. S. S.; FERREIRA, E. B.; OLIVEIRA, M. A. (2009) Studies on nonrandom patterns in Shewhart control charts. Gestão \& Produção (UFSCar). v: 16, n: 3, p. 414-421.

PAESE, C.; CATEN, C. T.; RIBEIRO, J. L. D. (2001) Aplicação da análise de variância na implantação do CEP. Produção. v. 11, n. 1, p. 17-26, nov.

R DEVELOPMENT Core Team. (2009) A language and environment for statistical computing. Foundation for Statistical Computing, Vienna, Austria. Disponível em: < http://www.R-project.org > Acesso em: 21 out. 2010.

RAMOS, A. W. (2000) CEP para processos contínuos e em bateladas. São Paulo. Edgard Blücher.

SCALCO, A. R.; TOLEDO, J. C. (2002) Gestão da qualidade em laticínios do estado de São Paulo: situação atual e recomendações. RAUSP. v. 37 , n. 2, p. 17-25, abr/jun.

SINGHA, R.; GILBREATHB, G. (2002) A real-time information system for multivariate statistical process control. International Journal Production Economics. v. 75, p.161-172.

SOUZA, A. F. C. (2006) Utilização de técnicas de análise multivariada para identificação do perfil dos laticínios de micro e pequeno porte do Estado de Minas Gerais. 2006. 96f. Dissertação (Mestrado em Ciência e Tecnologia de Alimentos) Universidade Federal de Viçosa. Viçosa.

SOUZA, A. M.; RIGÃO, M. H. (2005) Identificação de variáveis fora de controle em processos produtivos multivariados. Produção. v. 15, n. 1, p. 74-86, jan/abr.

TOLEDO, J. C.; BATALHA, M. O.; AMARAL, D. C. (2000) Qualidade na indústria agroalimentar: situação atual e perspectivas. Revista de Administração de Empresas (FGV). São Paulo. v. 40, n. 2, p. 90-101, abr/jun.

VIERIA, S. (1999) Estatística para a qualidade: como avaliar com precisão a qualidade em produtos e serviços. Rio de Janeiro: Elsevier. 
INDEPENDENT JOURNAL OF MANAGEMENT \& PRODUCTION (IJM\&P)

http://www.ijmp.jor.br

v. 5, n. 1, October - January 2014.

ISSN: 2236-269X

DOI: 10.14807/ijmp.v5i1.140

WINCKLER, N. C.; SANTOS, T. S.; MACHADO, J. A. D. (2013) Coopetition between household farmers of milk production chain in west of Santa. Revista Brasileira de Gestão e Desenvolvimento Regional. v. 9, n. 1, p. 40-66, jan/mar. 